JMKSP (Jurnal Manajemen, Kepemimpinan, dan Supervisi Pendidikan)

Volume 7 Issue 1 (2022) Page 110-120

ISSN 2614-8021 (Online) 2548-7094 (Print)

\title{
Establishment of Discipline Character and Responsibility Through Parenting Patterns
}

\section{Asep Muhamad Soleh ${ }^{1}$, Heri Sudarmaji ${ }^{2}$, Setiyo ${ }^{1}$, Bambang Wijaya Putra ${ }^{1}$, Sarah Jihan Khanna $\mathbf{S}^{1}$}

\author{
${ }^{1}$ Politeknik Penerbangan Palembang, ${ }^{2}$ Politkenik Penerbangan Surabaya \\ Corresponding Author E-mail: asep@ poltekbangplg.ac.id
}

Received 10 June 2021; Revised 30 September 2021; Accepted 11 January 2022

\begin{abstract}
Purpose of this study is to determine the character formation of discipline and responsibility through cadet parenting that has been carried out at the Palembang Civil Aviation Polytechnic. The parenting pattern is carried out by applying a strict schedule to the daily activities of the cadets based on the Cadets Code of Conduct. The research method is a qualitative research with a descriptive research model, to see how to strengthen the character of Palembang Civil Aviation Polytechnic cadets through parenting patterns. Collecting data by interview, observation and documentation. The results of the study show that the parenting pattern that is carried out can shape the character of discipline and responsibility for the Palembang Civil Aviation Polytechnic cadets. Based on this research, the formation of the character of discipline and responsibility of cadets can be formed through parenting patterns. So that parenting patterns can continue to be carried out with further development to shape future generations in the aviation sector in Indonesia.
\end{abstract}

Keywords: Parenting Pattern, Discipline Character, Responsibility Character

\section{Introduction}

Creating excellent, professional and ethical human resources is the vision carried by the Transportation Human Resources Agency. To implement this, 
while undergoing the education process, the transportation cadets must be equipped with character values that can achieve this vision. With the provision of good characters, it is hoped that they can quickly adapt and quickly interact with the surrounding environment. In the current era and in the future, the characters needed to equip cadets to live life are the character of discipline and responsibility. Discipline character needs to be displayed in each cadet, because the lives of most teenagers today are very dependent on their families through digital media. The second character that must be raised is the character of responsibility, which is very much needed for cadets in carrying out the tasks assigned to them. One of the student activities is to practice directly through the available simulation (Soleh, 2019).

According to Licknona (Fatonah, Wildan, Purnomo, \& Soleh, 2020) a person has a good character if he fulfills the components of moral knowing, moral feeling and moral action. So someone with good character, apart from having knowledge of morals, having moral feelings or being able to empathize, must also be able to carry out moral values. So the cadets must be useful people. Not people who do no action talk only, aka talk a lot but don't do anything.

Cadets are naturally like blank paper, which is still pure white, which will be formed through strengthening to become cadets and productive citizens (Watson, 2008). Thus cadets must be formed and educated to become human beings with character by institutions that already have a pattern of character education to shape the character of discipline and responsibility in each cadet. Of course, the education pattern must be well planned and implemented by the campus.

Character education must prioritize a critical attitude in analyzing problem phenomena in everyday life, not only concerned with cognitive aspects. The cognitive aspect is only limited to looking for numbers on a piece of paper. Whereas cognitive aspects can also be used to overcome problems in everyday life, for example in tackling stressful conditions (Rahmandani, 2015).

With the character of discipline and responsibility, it is hoped that the cadets can attend semi-military discipline-based education at the Palembang Aviation Polytechnic. Good character will be formed through the pattern of parenting education that has now been implemented, so it is hoped that later the output of cadets will produce cadets with character in accordance with what is needed by the aviation industry. Good character will support learning to achieve the expected 
competencies in accordance with regulations issued by the Directorate General of Civil Aviation (Soleh, Tobari, \& Kesumawati, 2019).

Character is the characteristic of each individual with regard to his identity, which is the essence of inner/spiritual qualities, ways of thinking, ways of behaving (outward attitudes and actions) of one's life and working together both in the family, community, nation and state (Maksudin, 2013). Character can also be interpreted as a basic value that builds a person's personality, formed both due to the influence of heredity and environmental influences, which distinguishes him from others, and is manifested in his attitudes and behavior in everyday life (Samani \& Haryanto, 2011). In psychology, the concept of "character" basically refers to the structure of personality, but in its development that meaning has undergone changes. The term was subsequently modified to reflect culturally valued attributes that reflect morality as defined by society (Allport, 1961).

In this millennial era, the younger generation uses smartphones a lot in their daily lives. The use of smart phones sometimes has a negative effect on the character of the youth of the nation's next generation. Therefore, young people must also be equipped with good disciplined characters in using smartphones so that the negative effects of using smartphones can be reduced to a minimum. One way to reduce the negative effects of using smartphones is to provide digital literacy that directs students to be responsible for the use of digital media, especially the use of social media (Soleh, Oka, \& Kristiawan, 2020).

In line with the research entitled establishment of character through boarding school in education students in Islamic boarding schools, it is stated that the establishment of discipline must have rewards and funishments, so that students can consistently apply good character values (Hasmayni, Siregar, \& Aziz, 2019). Also in a study entitled A Study Relationship Attitude Toward Physics, Motivation and Character Discipline Students of Senior High School In Indonesia, it is stated that the character of discipline is strongly influenced by the condition of students, the environment and the motivation of the students themselves (Darmaji, Astalini, Kurniawan, Perdana, \& Putra, 2019). Also in a study entitled Training Discipline and Responsibility: The Implementation of Values Clarification Model states that the cultivation of discipline and responsibility characters can be done with a predetermined clarification model, thus when we instill discipline and responsibility, the facilities must be available (Karim \& Mustadi, 2018). Also in a study entitled Implementation of Independence Character Education at Muhammadiyah Boarding School stated 
that the inculcation of independence character was carried out by habituation, integrated into learning and set forth in written regulations (Wuryandani, Fathurrohman, \& Ambarwati, 2016).

\section{Methods}

In this study, the author uses a qualitative research method with a descriptive research model, to see how to strengthen the character of Palembang Aviation Polytechnic cadets through parenting. Qualitative research is a scientific research that aims to understand a phenomenon in a natural social context by prioritizing a process of deep communication interaction between researchers and the phenomenon under study (Herdiansyah, 2013). While the descriptive research model is a research model that aims to provide a description of what is being studied. Although this research is not widespread, descriptive research is an indepth study (Herdiansyah, 2014).

The research was conducted in Palembang Civil Aviation Polytechnic. Data collection is done by interview and documentation. Primary data sources in this study include interviews. In addition to interviews with the subject, the author also conducted interviews with informants who were direct caregivers of the subject. Primary data or first-hand data, are data obtained directly from the subject as a source of information sought (Azwar, 2016).

In this study, the Researcher examined two subjects who had the same characteristics, among others, level 2 cadets in the Poliateknik Penerbangan Palembang, early adult male, regiment member, able to communicate well. The next data collection method is documentation. documentation is a method of collecting data by viewing or analyzing documents made by the subject himself or made by others about the subject. Documents are divided into two, namely personal documents and official documents. Personal documents are written records of a person, such as diaries, personal letters and autobiographies. The second is official documents, namely internal and external documents (Sugiyono, 2017).

The data analysis technique used in this study is an interactive model data analysis technique according to Miles \& Huberman (Herdiansyah, 2013), which consists of four stages that must be carried out, namely: Grouping the data, The first stage is grouping the data. The results of all data collection methods are made into written language; Data Reduction, Data reduction is the process of merging and homogenizing all forms of data obtained into one written form (script) to be analyzed. The results of the interview will be formatted into a verbatim interview. 
The results of observations and field findings are formatted into an adjusted table of observation results, the results of the documentation study are formatted into document analysis scripts.

The end of this stage is a collection of raw data that is already related to the guidelines; Data display, data display is a stage that is carried out after all data has been formatted based on data collection instruments and has been in written form. That is to make a selection again from an existing theme which is divided again into subthemes. In order, there will be three stages in the data display, namely the theme category, the theme subcategory, and the coding process. The three stages are interrelated with each other (Herdiansyah, 2014). The conclusion is the final stage of data analysis where the conclusions to be obtained come from the theme in the data display stage whose final goal is to answer questions on the research objectives.

\section{Results and Discussion}

\section{The Role of Caregivers of Cadets in Instilling Character Values}

In this study, we interviewed two caregivers who were the guardians of the cadets who were the research subjects. These caregivers are also from the official school within the Air Transportation Human Resources Development Center. The first caregiver is a woman who is a graduate of the Air Traffic Controller Study Program of the Indonesian Aviation Polytechnic Curug. While the second caregiver is male, who is a graduate of the Medan Aviation Polytechnic, majoring in Air Traffic Controller. These caregivers had previously been educated with parenting patterns as applied at the Palembang Civil Aviation Polytechnic.

In the parenting process, the caregiver is responsible for the parenting process carried out at the Palembang Civil Aviation Polytechnic. Every caregiver who is on duty has an obligation to supervise, guide and report on the daily activities of the cadets. All cadet activities have been regulated in the cadet code of conduct, starting from waking up, worship, sports activities, self-cleaning, eating, cleaning the environment to extracurricular activities.

The most important thing in parenting to form character is that a good example must be given to the cadets, be it by caregivers, lecturers and education staff at the Palembang Civil Aviation Polytechnic. As said by the first caregiver, that the example of the caregiver is very important to form the character of discipline and responsibility in cadets. If a cadet violates the provisions in the 
cadet code of conduct, the caretaker also does not immediately punish, but by giving a warning beforehand, because the function of the caregiver is as a guide for the cadets.

The role of the caregivers in the parenting pattern to form the character of discipline and responsibility for the cadets is as follows:

To train the cadets to carry out activities in the dormitory in all forms of activity. These activities are in the form of sports, as well as extra-curricular activities such as drum band, scientific paper, videography and others. Familiarize the cadets to carry out activities in accordance with the cadet rules and regulations that have been given by the caregivers. The proverb says that alah is possible because it is normal, therefore every cadet must get used to following the rules that have been set;

Supervise and monitor the cadets in carrying out daily activities in the dormitory. The cadets carry out their planned activities in accordance with the guidelines for the cadet rules. The role of the caregiver is to ensure that all cadets carry out all their activities according to the predetermined schedule; Providing counseling to cadets is the duty of the caregivers. All caregivers are given counseling knowledge so that all cadets will get counseling services, both academic and non-academic problems. If you need special counseling for psychological problems, then there are caregivers who are specifically educated in psychology to provide assistance;

In the process of implementing cadet care, there are cadets who violate the rules of daily activities. Therefore, the role of the caregiver is to provide punishment according to the level of violation committed by the cadets. Before being given a punishment, cadets will be given a warning not to repeat it again. But if a warning has been given, it is still a violation, then the duty of the caregiver is to give the punishment according to the cadet code of conduct; In addition to giving punishment, caregivers must also give rewards to cadets who excel in both academic and non-academic achievements. This reward is a reward for cadets who have implemented all the rules and some even exceed expectations in accordance with the cadet rules and regulations.

The results of observations made by researchers, cadet activities start from waking up at 04.30 in the morning, for those who are Muslim they carry out worship first. After carrying out the worship, all the cadets were ready to take part in the morning sports activities. The caregivers, of course, got up early to watch over or wake the cadets if anyone was still asleep. During the morning exercise, 
the activity was led by one of the picket cadets, who led the morning run and morning exercise. Meanwhile, caregivers play a role in supervising and observing if there are cadets who are sick or have health problems. If there are cadets who have health problems, the caregivers immediately refer to the pratama polyclinic at the Palembang Aviation Polytechnic.

Based on the above observations, the role of caregivers is very important in the process of implementing parenting patterns. Caregivers function as implementers, supervisors, protectors and also as those who give punishment if there are cadets who violate the cadet code of conduct. Caregivers work 24 hours a day and 7 days a week. So that the caregivers also feel the hard of the responsibility they carry in carrying out the parenting pattern at the Palembang Aviation Polytechnic. These caregivers work in coordination by the Head of the Character Development Center who is responsible for shaping the character of cadets during their education.

\section{Character of Discipline and Responsibility in Airport Management Program Cadets}

Researchers explore the character of discipline and responsibility by directly interviewing cadets using the prepared instruments. Interviews were conducted in a semi-structured manner, namely interviews using a question instrument guide that had been prepared as well as spontaneous questions that could support the results of the interviews comprehensively. Observations were also made on the daily lives of cadets in the dormitory and while attending lectures.

The results of interviews and observations of researchers on the character of the discipline and responsibility of the cadets who are the research subjects are as follows: The cadets always obey the cadet code of conduct, even though they have violated the cadet rules, but it is not a serious violation. For example, being late for breakfast or being late for morning parade; The cadets always do the tasks given by the caregivers and the assignments from the lecturers. The tasks given can be in the form of individual assignments or group assignments. If the assignments given are individual assignments, they always submit on time and the results of their work are in accordance with the expectations of the lecturers and caregivers. Likewise with group assignments. They can do well together in groups, so that the task can meet the expectations of the lecturers and caregivers.

The cadets always carry out sports activities according to the given schedule. In the morning together do a morning run, morning exercise. Push ups, sit ups and 
other exercises ordered by the caregiver. Likewise, in the afternoon after completing the training, the cadets carry out afternoon sports such as running and sports games, such as futsal, badminton, volleyball and others; The cadets carry out extra-curricular activities according to the activities they choose. There are drum band activities, scientific papers, video editors, art yati, and others. These extra-curricular activities are activities to channel the hobbies, talents and interests of cadets in fields other than academics.

In addition to cadet interviews, researchers also conducted interviews with caregivers about the discipline character and responsibility character of the cadets. The results from the interviews with the first caregiver and second caregiver are as follows: In general, the cadets are very disciplined, they obey and implement all the rules contained in the cadet rules and regulations. But indeed, sometimes cadets violate the rules, only minor violations. If they commit minor violations, the cadets are only warned by giving a punishment in the form of push ups at the scene. Until now, caregivers have never given severe punishment to cadets. This means that in general the cadets have been disciplined in carrying out the rules contained in the cadet code of conduct; All cadet activities have been planned in accordance with the cadet code of conduct issued by the Palembang Aviation Polytechnic. In the guideline, it is clearly written what cadets must do in their daily activities, from waking up to sleeping again. The implementation of cadet activities is coordinated by the Head of the Character Development Center and carried out in the field by the caregivers 24 hours a day and 7 days a week.

The activities of the cadets are not only physical in nature, but also spiritual activities. Every Thursday night Islamic spiritual activities are held in the form of recitations which are carried out in the prayer room and in the dormitory. Christians also carry out spirituality which is carried out in the dining room. For those who are Hindus, they also carry out spirituality which is in a different room from the spirituality of other religions. All spiritual activities are guided by leaders according to their respective religions. To train the cadets' sense of responsibility, they are given tasks in the form of activities carried out for certain events. For example, there is an activity to commemorate the independence day of the Republic of Indonesia. So all cadets are given their respective duties and responsibilities. Some served as flag raisers, as text readers, as company commanders, as platoon commanders, as presenters and so on. They carry out all the tasks assigned to them with full responsibility, so that the event can be carried out properly and according to expectations. 


\section{Factors Affecting the Process of Instilling Character Values}

There are several factors that influence the process of instilling character values into cadets, namely the availability of cadet rules and regulations that must be carried out by cadets. In addition, caregivers, lecturers and education staff must be role models for cadets in developing good character (Riyanto \& Rivolindo, 2019). Caregivers can also be supervisors for the implementation of cadet discipline, who can reprimand directly to cadets if they do not follow the rules. Another factor is the willingness of the cadets themselves to follow and obey the cadets' code of conduct. If everything can synergize then the good character of the cadets will grow quickly and develop.

Another influencing factor is the environment in which education takes place. If the environment is conducive, orderly and complete with adequate facilities, the character inculcation of the cadets will also be fast (Basyaruddin \& Rifma, 2020) . Every day the cadets carry out their duties, starting with waking up, worshiping, exercising and then cleaning up. At breakfast all the cadets entered the dining room in an orderly manner. When the meal begins with a prayer that the cadets guard, then eat using good eating procedures and ends with a closing meal. Every activity is carried out in accordance with the rules that have been set.

Based on the observations and interviews that have been carried out, it can be stated that the factors that influence the growth of the character of discipline and responsibility in cadets are the rules of cadet rules (Kristiawan, Marryanti, \& Fitria, 2020). In addition, the caregiver factor greatly influences the creation of a disciplined and responsible character for cadets. Therefore, the condition of the influence must always be in good health and in good psychological condition, because it will affect the mental and character of the cadets.

\section{Conclusion}

The discipline and responsibility character education carried out at the Palembang Aviation Polytechnic has been going well. Character education is carried out through a planned parenting pattern, guided by competent caregivers and the availability of written rules in the form of cadet discipline guidelines. The results of the study indicate that the cadets have embedded the character of discipline and responsibility as expected. In implementing the parenting pattern, strict supervision from caregivers is needed for 24 hours a day, therefore it is necessary to have a proper number of caregivers in accordance with the ratio of the number of cadets to obtain more optimal character education results. 


\section{References}

Allport, G. W. (1961). Personality: A psychological interpretation. New York: Henry Holt \& Company.

Azwar, S. (2016). Metode Penelitian [Research methods]. Yogyakarta: Pustaka Pelajar.

Basyaruddin, N. Y., \& Rifma. (2020). Evaluasi Penguatan Pendidikan Karakter

[Evaluation of Strengthening Character Education]. JMKSP(Jurnal Manajemen, Kepemimpinan, dan Supervisi Pendidikan), 14-20.

Darmaji, Astalini, Kurniawan, D. A., Perdana, R., \& Putra, D. S. (2019). A Study Relationship Attitude Toward Phyisics, Motivation and Character Discipline

Students Senor High School In Indonesia. International Journal of Learning and Teaching, 99-109.

Fatonah, F., Wildan, M., Purnomo, S., \& Soleh, A. M. (2020). Design Of High Gain Low Noise Amplifier At Base Station Receiver VOR Equipment For Ground Check Monitoring As Learning Media In Civil Aviation Academy. International Journal of Progressive Sciences and Technologies, 397-402.

Hasmayni, B., Siregar, F. H., \& Aziz, A. (2019). Establishment of Character Through Boarding School education in Student in Pondok Pesantren. Advance in Social Science Education and Humanities Research, 238-241.

Herdiansyah, H. (2013). Wawancara, Observasi dan Focus Groups [Interviews,

Observations and Focus Groups]. Depok: PT. Raja Grafindo Persada.

Herdiansyah, H. (2014). Metodologi Penelitian Kualitatif [Qualitative Research Methodology]. Jakarta: Salemba Humanika.

Karim, I. M., \& Mustadi, A. (2018). Training Discipline and Responsibility: The Implementation of Values Clarification Model. Jurnal Pena Sains, 37-48.

Kristiawan, M., Marryanti, N., \& Fitria, H. (2020). Membangun Karakter Peserta Didik Melalui Green School di SMK Negeri 2 Muara Enim [Building Student Character Through Green School at SMK Negeri 2 Muara Enim]. JMKSP (Jurnal Manajemen, Kepemimpinan, dan Supervisi Pendidikan), 210-217.

Maksudin. (2013). Pendidikan Karakter Non-Dikotomik [Non-Dichotomous Character Education]. Jogjakarta: Pustaka Pelajar.

Rahmandani, A. (2015). Pemaafan dan Aspek Kognitif dari Stress pada Mahasiswi Jurusan Kebidanan Tingkat Dua [Forgiveness and Cognitive Aspects of Stress in Midwifery Students Level Two]. Jurnal Psikologi 
Undip, 112-118.

Riyanto, B., \& Rivolindo. (2019). Pola Pengasuhan Taruna Berbasis Keteladanan Pada Taruna Politeknik Pelayaran Sumatera Barat [Parenting Patterns for Cadets Based on Exemplary At Cadets of the West Sumatra Shipping Polytechnic]. JMKSP (Jurnal Manajemen, Kepemimpinan, dan Supervisi Pendidikan, 218-224.

Samani, M., \& Haryanto. (2011). Konsep dan Model Pendidikan Karakter [Character Education Concepts and Models]. Bandung: Remaja Rosdakarya.

Soleh, A. M. (2019). Pengembangan Media Simulator pada Pendidkan dan Pelatihan Foam Tender Operation and Defensive Driving di Balai Pendidikan dan Pelatihan Penerbangan Palembang [Development of Simulation Media in Foam Tender Operation and Defensive Driving Education and Training at the Palembang Aviation Education and Training Center]. Prosiding Seminar Nasional Program Pascasarjana Universitas PGRI Palembang, 108-119.

Soleh, A. M., Oka, I. A., \& Kristiawan, M. (2020). Kondisi Literasi Media Digital dalam Aktifitas Kerja Pegawai Politeknik Penerbangan Palembang [Digital Media Literacy Conditions in Palembang Aviation Polytechnic Employees' Work Activities]. Ilmu Pendidikan Jurnal Kajian Teori dan Praktik Kependidikan, 51-61.

Soleh, A. M., Tobari, \& Kesumawati, N. (2019). Development Of The Practical Manual As A Learning Media For SimulatorAircraft Rescue And Fire Fighting. International Journal Of Scientific \& Technology Research, 523526.

Sugiyono. (2017). Metode Penelitian Pendidikan Pendekatan Kuantitatif, Kualitatif dan R\&D [Educational Research Methods Quantitative, Qualitative and R\&D Approaches]. Bandung: Alfabeta.

Watson, M. (2008). Development Discipline and Moral Education (Handbook of Moral and Character by Nucci \& Narvaez)). New York: Routledge.

Wuryandani, W., Fathurrohman, \& Ambarwati, U. (2016). Implementasi

Pendidikan Karakter Kemandirian di Muhammadiyah Boarding School [Implementation of Independence Character Education at Muhammadiyah Boarding School]. Cakrawala Pendidikan, 208-216. 